\title{
EFIKASI DIRI DALAM MEMBUAT KEPUTUSAN KARIER PADA MAHASISWA
}

\section{CAREER DECISION MAKING SELF EFFICACY IN COLLEGE STUDENTS}

\author{
Fitria Rahmi \\ Universitas Andalas \\ fitriarahmi01@gmail.com
}

\begin{abstract}
Abstrak
Efikasi diri dalam membuat keputusan karier (Career Decision Making Self Efficacy/CDMSE) merupakan keyakinan individu bahwa dirinya dapat secara sukses melakukan tugas-tugas yang berkaitan dengan pengambilan keputusan karier. Fenomena yang terjadi saat ini masih banyak mahasiswa yang bingung dengan pekerjaan yang akan dipilihnya. Tidak sedikit yang kesulitan untuk membuat keputusan terhadap pilihan karier kedepannya. Hal ini tentu akan menghambat dalam mencapai tugas perkembangan karier mereka. Penelitian ini bertujuan untuk mengetahui bagaimana gambaran efikasi diri mahasiswa dalam membuat keputusan karier. Penelitian ini merupakan penelitian kuantitatif deskriptif. Data diperoleh dari 824 orang mahasiswa Universitas Andalas dengan menggunakan alat ukur CDMSE-Short Form (Betz, Klein \& Taylor, 1996). Hasil penelitian diperoleh bahwa sebanyak 576 orang mahasiwa $(69.90 \%)$ memiliki efikasi diri kategori sedang dalam membuat keputusan karier. Selanjutnya efikasi diri dalam membuat keputusan karier pada kategori tinggi dan rendah memiliki persentase yang hampir sama yaitu sebesar $14.93 \%$ dan $15.17 \%$. Lebih lanjut hasil penelitian akan dibahas dalam diskusi penelitian.
\end{abstract}

Kata Kunci : Efikasi diri, Keputusan Karier, Mahasiswa

\begin{abstract}
Career Decision Making Self Efficacy (CDMSE) is an individual belief that can successfully perform tasks related to career decision making. The current phenomenon, still many students are confused about the work that they will choose. A lot of students have difficulty in making decisions about their future career choices. This will certainly hamper them in achieving their career development tasks. This study aims to find out how the image of student self-efficacy in making career decisions looks like. This research is descriptive quantitative research. Data were obtained from 824 students of Andalas University that used the CDMSEShort Form measurement tool (Betz, Klein \& Taylor, 1996). The results of the study showed that 576 students $(69.90 \%)$ had moderate self-efficacy in making career decisions. Furthermore, self-efficacy in making career decisions in the high and low categories has almost the same percentage of $14.93 \%$ and $15.17 \%$. Further research results will be discussed in the research discussion.
\end{abstract}

Keywords: Self-efficacy, Career Decision, College Student

\section{PENDAHULUAN}

Pekerjaan atau karier menjadi aspek penting dalam memenuhi kebutuhan dan meningkatkan harga diri seseorang. Menurut Seligman (dalam Podiaro, Soetjiningsih, \& Prasetya, 2014) pekerjaan yang dilakukan seseorang merupakan bagian dari perkembangan karier. Pada setiap tahap perkembangan karier menurut Super (dalam Brown, 2002), seseorang dituntut untuk menyelesaikan berbagai tugas perkembangan. Seseorang yang mampu menyelesaikan tugas pada setiap tahap perkembangan kariernya akan membawa kesuksesan pada perjalanan kariernya, tak terkecuali mahasiswa yang masuk dalam kategori dewasa muda. 
Papalia, Olds dan Fieldman (2008) menjelaskan bahwa individu dalam usia dewasa muda berada pada tahap perkembangan dimana mereka menggunakan pengetahuannya untuk mengejar target seperti karier dan keluarga. Mahasiswa merupakan kelompok individu yang termasuk dalam kategori dewasa muda, oleh sebab itu, mahasiswa juga diharapkan mampu mempersiapkan masa depan termasuk dalam hal karier. Mahasiswa diharapkan mampu menentukan karier yang ditekuni dikemudian hari dan mulai mempersiapkan diri. Pemilihan bidang pekerjaan berkaitan erat dengan penentuan program pendidikan, karena suatu bidang pekerjaan menuntut seseorang untuk menyelesaikan pendidikan dan pelatihan tertentu sesuai dengan tuntutan pekerjaan tersebut (Malik, 2015).

Fenomena yang terjadi adalah masih banyak mahasiswa yang bingung dengan pekerjaan apa yang akan dipilihnya. Tidak sedikit yang kesulitan untuk membuat keputusan terhadap pilihan karier kedepannya. Berdasarkan data dari badan survey nasional di Amerika Serikat tahun 1999, sebanyak 50\% mahasiswa perguruan tinggi tidak dapat memutuskan bagaimana karier mereka kedepannya (GiankosdalamDybwad, 2009).

Membuat keputusan karier pada dasarnya memang merupakan tugas yang sulit dan membingungkan bagi sebagian mahasiswa perguruan tinggi, namun keputusan tersebut menjadi hal penting yang akan mempengaruhi sebagian besar kehidupan mereka (Vahedi, Farrokhi, Mahdavi, \& Moradi, 2012). Sulitnya membuat keputusan karier karena masih bingung berdampak pada kehidupan yang mereka jalani setelah selesai perkuliahan dimana masih banyak yang menganggur. Menurut data BPS tingkat pengangguran terbuka (TPT)di Indonesia periode Februari 2015 yaitusebesar 5,81\% atau jika ditotal mencapai 7,45 juta orang. Di Sumatera Barat padaFebruari 2015 tercatat TPT sebesar 5,99\% (sekitar 148,68 ribu orang), dimana pengangguran yang berasal dari lulusan universitas menempati salah satu peringkat teratas dengan jumlah 16,04 ribu orang $(11,10 \%)$.

Banyaknya jumlah pengangguran yang berasal dari perguruan tinggi disebabkan oleh banyak hal. Survei yang dilakukan oleh Kasih \& Suganda (dalam Rachmawati, 2012) mengungkapkan $91 \%$ dari lulusan perguruan tinggi dinilai tidak dapat menghasilkan lulusan siap pakai, adanya ketidaksesuaian antar output pendidikan dengan tuntutan perkembangan ekonomi, serta kualitas lulusan yang tidak sesuai dengan kebutuhan dunia kerja. Kurangnya persiapan, baik penyesuaian diri mahasiswa dengan persyaratan pasar kerja dan kurangnya informasi mengenai dunia kerja menyebabkan tingginya tingkat pengangguran diantara lulusan perguruan tinggi. Faktor lain yang paling penting berasal dari individu itu sendiri sehingga menyebabkan kegagalan dalam memperoleh pekerjaan dikarenakan individu tidak memiliki informasi yang relevan mengenai pekerjaan yang tersedia dengan kemampuan yang dimiliki sehingga belum bisa memutuskan pilihan pekerjaannya (Sawitri, 2008).

Masih banyaknya mahasiswa yang kesulitan dalam membuat keputusan karier tentu akan menghambat mereka dalam mencapai tugas perkembangan karier mereka. Munculnya fenomena 
ini mendorong peneliti untuk melakukan penelitian di Universitas Andalas (Unand) didasarkan pada hasil studi terdahulu. Hasil penelitian terbaru di Unand ditemukan bahwa sebagian besar mahasiswa mengalami kesulitan pengambilan keputusan karier. Kesulitan yang paling tinggi yaitu kurangnya kesiapan (lack of readiness) dalam mengambil keputusan karier karena kepercayaan irasional (dysfunctional beliefs) yang muncul sebelum dimulainya proses pengambilan keputusan karier, sehingga menghalangi mahasiswa dalam membuat keputusan (Putri, 2017). Hal ini maka dapat dikatakan bahwa ketika mahasiswa punya pemikiran yang irasional ia menjadi kurang percaya pada kemampuannya membuat keputusan terhadap pilihan karier tertentu. Berbeda jika sebaliknya ia memiliki keyakinan dan percaya bahwa ia dapat membuat keputusan maka ia akan berusaha lebih keras dan bertahan ketika menemui kesulitan. Ia akan memfokuskan perhatian dan lebih optimis dalam menetapkan strategi yang akan dipilih untuk membuat keputusan. Dengan kata lain keyakinan diri atau efikasi dirinya menggerakkan faktor kognitif dan motivasinya sehingga mendorong mahasiswa tersebut untuk membuat sebuah keputusan dalam memilih karier tertentu.

Banyaknya tantangan semakin mempersulit seseorang untuk membuat keputusan karier. Kesulitan dalam membuat keputusan karier ini berhubungan dengan bagaimana seseorang menilai kemampuan dirinya dalam menghadapi tantangan tersebut (Santosa \& Himam, 2014). Membuat keputusan karier adalah salah satu tugas yang penting dan tak terelakkan (Buyukgoze-Kavas, 2014). Pemilihan karier merupakan salah satu keputusan paling penting dalam kehidupan individu. Keputusan mengenai karier melibatkan banyak faktor yang membentuk jalur dalam diri individu (Damayanti \& Widyowati, 2018).

Kesulitan pengambilan keputusan karier yang dialami oleh mahasiswa Universitas Andalas perlu mendapat perhatian baik dari individu yang bersangkutan maupun dari pihak kampus. Menurut Super dkk (1981), rendahnya aspek decision making yang dimiliki oleh seorang mahasiswa menunjukkan rendahnya kesiapan dalam membuat keputusan karier untuk dirinya sendiri.

Kesiapan membuat keputusan karier berkaitan dengan efikasi diri mahasiswa terhadap kemampuannya. Menurut Umam (2015), efikasi dirimemiliki peran penting dalam mempengaruhi usaha yang dilakukan seseorang, seberapa kuat usahanya dan memprediksi keberhasilan yang akan dicapai. Efikasi diri dalam membuat keputusan karier (Career Decision Making Self Efficacy/CDMSE) merupakan keyakinan individu bahwa dirinya dapat secara sukses melakukan tugas-tugas yang berkaitan dengan pengambilan keputusan karier (Taylor \& Betz, dalam Wang et al., 2006; Widyaningrum \& Hastjarjo, 2016). Penelitian Creed, Patton, dan Watson, (2003), menyimpulkan bahwa seseorang yang memiliki CDMSE yang tinggi meskipun tidak stabil dalam pola pemilihan kariernya tetap akan menunjukkan perilaku konsisten untuk menyelesaikan tugas karier yang telah dipilihnya.

Beranjak dari fenomena ini maka penting dilakukan penelitian untuk melihat bagaimana gambaran efikasi diri dalam membuat keputusan terutama pada mahasiswa Unand. Harapannya 
penelitian ini dapat memberikan gambaran menyeluruh yang dapat membantu pihak universitas dalam menangani dan memberikan treatment yang tepat untuk mempersiapkan sumber daya yang lebih berkualitas dan memiliki daya saing di dunia kerja.

\section{Efikasi Diri dalam Membuat Keputusan Karier (Career Decision Making Self Efficacy)}

Pengambilan keputusan karier berkaitan dengan keyakinan diriindividu dalam mengambil keputusan. Para ahli telah membuat sebuah konstruk utuh untuk menjelaskan efikasi diri dalam membuat keputusan karier atau yang disebut dengan istilah Career Decision Making Self Efficacy (CDMSE). Taylor dan Betz (1983) adalah ahli yang pertama membuat konstruk tersebut. Taylor dan Betz mendefinisikan efikasi diri dalam membuat keputusan karier sebagai keyakinan individu untuk dapat dengan sukses menyelesaikan tugas-tugas yang dibutuhkan dalam membuat keputusan karier (Bozegeyikli, Banali, \& Dogan, 2009).

Efikasi diri dalam pengambilan keputusan adalah keyakinan individu pada kemampuan mereka untuk membuat keputusan karier (Betz \& Luzzo, 1996), Hal ini terkait dengan konsep selfefficacy Bandura, yang berarti bahwa keyakinan seseorang terhadap kemampuannya untuk berhasil akanmempengaruhi pilihan perilaku dan kinerjanya (Betz, Klein, \& Taylor, 1996).

Penerapan teori self efficacy yang disusun oleh Bandura berkaitan dengan teori mengenai pengembangan karier oleh Hacket dan Betz pada tahun 1983. JikaTeori self efficacyBandura diterapkan untuk pengambilan keputusan karier, maka rendahnya tingkat efikasi diri dalam membuat keputusan karier dapat menghambat keputusan karier, sedangkan tingkat self efficacyyang tinggi dalam keputusan karier akan berdampak pada meningkatnya keterlibatan dalam perilaku membuat keputusan karier (Luzzo, dalam Tomevi, 2013). Individu dengan efikasi diri tinggi dalam membuat keputusan lebih suka dengan keputusan yang lebih menantang dan kompleks (Tabernero \& Wood, 2009), dan mencari informasi lebih lanjut ketika membuat keputusan (Seijts, Latham, Tasa, \& Latham, 2004).

Efikasi diri mengacu pada keyakinan seseorang terhadap kemampuan untuk berhasil dalam tugas yang diberikan (Chung, 2002; Bandura dalam Reed, Mikels \& Löckenhoff, 2012), mendorong individu untuk memilih tugas yang lebih menantang dan bertahan lebih banyak dalam menghadapi tantangan tersebut. Efikasi diri dalam membuat keputusan karier memerlukan kepercayaan intdividu terhadap kemampuannya dalam membuat keputusan yang efektif sehingga mempengaruhi preferensi dalam pemilihan karier.

Menurut Caprara, Scabini, dan Regalia (dalam Sawitri, 2009; dalam Damayanti \& Widyowati, 2018) bahwa efikasi diri dalam keputusan karier tidak datang dengan sendirinya, tetapi merupakan merupakan hasil dari berbagi pengetahuan dan tanggung jawab, hubungan yang beragam, tugas-tugas yang bermanfaat, dan interaksi dengan orang lain sebagai acuan dalam menentukan tindakan atau keputusan dalam pilihan karier seseorang. 
Terdapat lima domain untuk mengukur efikasi diri dalam membuat keputusan (dalamBetz \& Luzzo 1996; Betz \& Hackett, 2006), yaitu :

a. Self-appraisal (penilaian diri)

b. Gathering occupational information (pengumpulan informasi tentang pekerjaan),

c. Goal selection (penentuan tujuan),

d. Planing (perencanaan),

e. Problem solving (penyelesaian masalah),

\section{METODE}

Jenis penelitian ini adalah penelitian kuantitatif deskriptif. Peneliti ini mendeskripsikan bagaimana gambaran efikasi diri dalam membuat keputusan karier pada mahasiswa. Efikasi diri dalam membuat keputusan karier adalah keyakinan mahasiswa untuk dapat sukses menyelesaikan tugas yang diperlukan dalam mengambil keputusan karier. Efikasi diri dalam membuat keputusan karier diperoleh dari skor nilai alat ukur CDMSE Short-Form Scale yang mengacu pada teori Crites (1978) (Betz, Klein, \& Taylor, 1996; Betz, Hammond, \& Multon, 2005) dilihat dari lima aspek yaitu Self appraisal, Occupational information, Goalselection, Planning, dan Problem solving. Semakin tinggi skor total yang diperoleh individu, menunjukkan semakin tinggi efikasi diri dalam membuat keputusan karier pada individu begitu sebaliknya.

Penelitian ini melibatkan subjek sebanyak 824 orang mahasiswa S1 Universitas Andalas (Unand) yang berasal dari 14 Fakultas. Teknik sampel yang digunakan dalam penelitian ini yaitu kluster random sampling. Setelah dikelompokkan dan disampling menurut klusternya kemudian dilakukan random untuk memilih kelas yang akan dijadikan sampel pada masing-masing angkatan secara acak.

Pengumpulan data dalam penelitian ini menggunakan skala psikologi yang melibatkan angkatan yang masih aktif mulai dari 2014 sampai dengan angkatan 2016. Efikasi diri dalam membuat keputusan karierdiukur menggunakan CDMSE-Short Form yang berjumlah 25 aitem. Betz, Klein, dan Taylor (1996) menemukan koefisien reliabilitas untuk skala secara keseluruhan adalah 0,94 , dan koefisien mulai dari 0,73 sampai 0,83 untuk sub-skala. Skala ini menggunakan 5 level respon mulai dari level 1 (tidak percaya diri) sampai level 5 (sangat percaya diri).

Berdasarkan hasil uji coba diperoleh nilai koefisien reliabilitas $(\alpha)$ untuk skala CDMSEsebesar 0.911, dengan aitem yang gugur yaitu item no 13. Koefisien korelasi item total CDMSE memiliki rentang 0.264-0.724. Menurut Azwar (2012) pemilihan aitem yang diterima didasarkan pada kriteria batasan korelasi aitem total sama dengan atau lebih besar dari $(\geq) 0.25$. Berdasarkan hasil yang diperoleh, aitem no 13 gugur karena memiliki nilai korelasia item total kurang dari 0.25 . Selanjutnya peneliti mengolah data menggunakan analisis data secara kuantitatif dengan teknik analisis statistik deskriptif, yang kemudian diolah dengan program komputer SPSS. 
Penelitian ini mengelompokkan variabel CDMSE menggunakan kategorisasi tinggi, sedang, dan rendah.

\section{HASIL DAN PEMBAHASAN}

Hasil analisa data terhadap 824 orang diperoleh bahwa secara umum efikasi diri mahasiswa dalam membuat keputusan karier berada pada kategori sedang yaitu sebesar 69,90\%. Selanjutnya sebesar $15,17 \%$ pada kategori rendah dan sebesar 14,93\% berada pada kategori tingi Kategorisasi interpretasi skor efikasi diri dalam membuat keputusan karier dapat dilihat pada tabel di bawah ini:

Tabel 1. Kategorisasi skor CDMSE

\begin{tabular}{ccccc}
\hline Rumus & Skor & Kategorisasi & Frekuensi & Persentase \\
\hline$X<(\mu-1,0 \square)$ & $X<71.571$ & Rendah & 125 & $15,17 \%$ \\
$(\mu-1,0 \square) \leq X<(\mu+1.0 \square)$ & $71.571 \leq X<98.169$ & Sedang & 576 & $69,90 \%$ \\
$(\mu+1,0 \square) \leq X$ & $98.169 \leq X$ & Tinggi & 123 & $14,93 \%$ \\
\hline
\end{tabular}

Kategorisasi interpretasi skor efikasi diri dalam membuat keputusan karier berdasarkan masing-masing aspek, secara rinci dapat dilihat pada tabel berikut ini:

Tabel 2. Kategorisasi skor subjek berdasarkan aspek CDMSE

\begin{tabular}{|c|c|c|c|c|}
\hline \multirow{2}{*}{ Aspek } & \multirow{2}{*}{ Skor } & \multirow{2}{*}{ Katagori } & \multicolumn{2}{|c|}{ Subjek } \\
\hline & & & $\mathbf{F}$ & $(\%)$ \\
\hline \multirow{3}{*}{ Self Appraisal } & $\mathrm{X}<14,911$ & Rendah & 117 & $14,20 \%$ \\
\hline & $14,911 \leq X<21,309$ & Sedang & 582 & $70,63 \%$ \\
\hline & $21,309 \leq X$ & Tinggi & 125 & $15,17 \%$ \\
\hline \multicolumn{3}{|c|}{ Jumlah } & 824 & $100 \%$ \\
\hline Gathering & $\mathrm{X}<14,126$ & Rendah & 155 & $18,81 \%$ \\
\hline Occupational & $14,126 \leq X<20,454$ & Sedang & 548 & $66,51 \%$ \\
\hline Information & $20,454 \leq X$ & Tinggi & 121 & $14,68 \%$ \\
\hline \multicolumn{3}{|c|}{ Jumlah } & 824 & $100 \%$ \\
\hline \multirow{3}{*}{ Goal Selection } & $X<14,557$ & Rendah & 119 & $14,44 \%$ \\
\hline & $14,557 \leq X<20,943$ & Sedang & 557 & $67,60 \%$ \\
\hline & $20,943 \leq X$ & Tinggi & 148 & $17,96 \%$ \\
\hline \multicolumn{3}{|c|}{ Jumlah } & 824 & $100 \%$ \\
\hline \multirow{4}{*}{ Planning } & $X<14,65$ & Rendah & 120 & $14,56 \%$ \\
\hline & $14,65 \leq X<21,11$ & Sedang & 601 & $72,94 \%$ \\
\hline & $21,11 \leq \mathrm{X}$ & Tinggi & 103 & $12,5 \%$ \\
\hline & \multicolumn{2}{|l|}{ Jumlah } & 824 & $100 \%$ \\
\hline \multirow{4}{*}{ Problem Solving } & $\mathrm{X}<11,42$ & Rendah & 134 & $16,26 \%$ \\
\hline & $11,426 \leq X<16,26$ & Sedang & 574 & $69,66 \%$ \\
\hline & $16,26 \leq X$ & Tinggi & 116 & $14,08 \%$ \\
\hline & \multicolumn{2}{|l|}{ Jumlah } & 824 & $100 \%$ \\
\hline
\end{tabular}

Berdasarkan tabel di atas dapat dilihat bahwa semua aspek efikasi diri dalam membuat keputusan berada pada kategori sedang dengan masing-masing persentase yaitu aspek self appraisal 70,63\%, gathering occupational information 66,51\%, aspek goal selection sebesar $67,60 \%$, planning dengan persentase $72.94 \%$, dan terakhir aspek problem solving sebesar $69,66 \%$. 
Selanjutnya, dari kelima aspek persentase kategori rendah dengan nilai lebih besar ada pada aspek Gathering occupational information sebesar 18,81\% diikuti oleh aspek problem solving dengan persentase pada kategori rendah sebesar 16,26. Sedangkan aspek goal selection memiliki persentase kategori tinggi dengan nilai paling besar diantara aspek lainnya yaitu sebesar 17,96\%.

Hasil analisis kuantitatif secara deskriptif pada variabel efikasi diri dalam membuat keputusan karier menunjukkan bahwa secara umum efikasi diri mahasiswa Unand dalam membuat keputusan karier berada pada kategori sedang. Ini berarti bahwa sebagian subjek dalam penelitian sudah memiliki efikasi diri dalam membuat keputusan karier, namun sebagian lainnya masih belum atau berada pada kategori rendah. Atau dengan kata lain sebagian besar mahasiswa dalam penelitian ini masih belum sepenuhnya memiliki keyakinan untuk dapat sukses menyelesaikan tugas yang diperlukan dalam mengambil keputusan terhadap karier mereka.

Individu yang yakin terhadap kemampuannya dalam mengambil keputusan tentang karier dimasa depan, mereka akan mencoba melakukan sesuatu, mempunyai harapan terhadap hasil perilaku tersebut dan berperilaku dengan cara-cara yang diarahkan untuk membantu pencapaian tujuan-tujuannya (Stitt-Gohdes,1997). Hanya saja dari hasil penelitian ditemukan bahwa belum semuanya mahasiswa memiliki kepercayaan diri dalam menyelesaikan tugas untuk membuat keputusan karier. Atau dengan kata lain mahasiswa belum sepenuhnya yakin bahwa ia dapat terlibat dalam kegiatan seperti melakukan penilaian diri yang akurat, mengumpulkan informasi pekerjaan yang relevan, memilih tujuan karier yang tepat, membuat perencanaan untuk masa depan serta inisiatif mengatasi persoalan terkait dengan pilihan kariernya.

Pada dasarnya pengambilan keputusan karier melibatkan beberapa keterampilan diantaranyamengumpulkan informasi tentang berbagai macam pilihan pekerjaan, menilai kemampuan dan minat, menyeleksi tujuan yang ingin dicapai sesuai dengan pekerjaan yang tepat, membuat perencanaan aksi untuk mencapai tujuan yang ingin dicapai dan membuat strategi untuk mengelolamasalah ketika muncul masalah dalam pekerjaan (Crites, dalam Bandura, 1997).

Lebih lanjut hasil penelitian ini mendukung penemuan sebelumnya oleh Pratiwi (2015) terutama dalam aspek pengambilan keputusan karier. Dimana sebanyak 69.3\% mahasiswa berada pada kategori sedang dan $17.2 \%$ pada kategori rendah, ini berarti mahasiswa belum sepenuhnyasiap untuk membuat keputusan mengenai pekerjaan yang akan dijalaninya. Kesulitan dalam membuat keputusan karier dapat disebabkan oleh kurangnya kesiapan dalam memulai proses pengambilan keputusan karier. Hal ini sesuai dengan hasil penelitian Putri (2017) dimana kesulitan pengambilan keputusan karier yang paling tinggi berasal dari kurangnya kesiapan (lack of readiness) dalam mengambil keputusan karier sehingga menghalangi mahasiswa dalam membuat keputusan.

Jika melihat hasil kategorisasi per aspek, dapat disimpulkan secara keseluruhan subjek dalam penelitian memiliki skor pada kategori sedang, baik pada aspek Self appraisal (penilaian diri) gathering occupational information (informasi pekerjaan), Goal selection (pemilihan tujuan), 
Planning (perencanaan), Problem solving (pemecahan masalah). Ini berarti bahwa sebagian mahasiswa sudah memiliki keyakinan bahwa mereka mampu membuat penilaian terhadap kemampuan diri mereka; memiliki informasi pekerjaan terhadap pekerjaan yang diminati, menetapkan tujuan kariernya; yakin akan kemampuan membuat perencanaan karier; serta memiliki keyakinan dalam mengatasi persoalan yang dihadapi; sebaliknya sebagian lainnya masih menunjukkan keraguan dan kurang yakin terhadap kemampuan diri mereka mencapai kelima aspek tersebut.

Lebih lanjut berdasarkan hasil penelitian diperoleh bahwa pada aspek gathering occupational informationmemiliki skor kategori rendah sebesar $18.81 \%$, dimana nilai persentase tersebut lebih tinggi dibanding skor kategori rendah pada empat aspek lainnya. Ini berarti kurang yakinnya mahasiswa dalam membuat keputusan karier salah satunya disebabkan karena masih kurangnya kemampuan dalam mengumpulkan informasi terkait pekerjaan apa yang akan digeluti nantinya. Mahasiswa masih kurang memperoleh pengetahuan mengenai hal apa yang harus dipertimbangkan dalam memilih pekerjaan setelah kuliah. Jika melihat kondisi Unand sendiri, keberadaan pelayanan pusat karier dan konseling masih perlu ditingkatkan dalam pelaksanaan program-programnya sehingga lebih maksimal dalam menyediakan informasi karier terhadap calon lulusan sarjana dan alumni.

Hasil penelitian ini mendukung penelitian yang dilakukan Vertberger dan Gati (2016) dimana sebanyak 57\% sampel yang diteliti menyatakan bahwa membuat keputusan karier merupakan tugas yang menyulitkan bagi mereka. Hambatan terbesar yang menyebabkan mereka sulit membuat keputusan karena kurangnya informasi (lack of information). Kurangnya informasi bisa saja mengenai diri, karier, ataupun mengenai cara memperoleh informasi tambahan. Dalam penelitian ini mahasiswa masih terbatas kemampuan untuk menggambarkan minat terhadap suatu pekerjaan, dengan mencari informasi, tambahan tentang bidang karier yang dipilih maupun informasi tentang dunia kerja secara umum (seperti trend, sikap, dan kesempatan kerja).

Banyak tugas yang berkaitan dengan karier secara inheren bersifat sosial atau interpersonal seperti mencari informasi karier dari teman dan keluarga, kenalan, dan melamar serta mencari tahu tentang pekerjaan (Phillips \& Bruch dalam Wang et al., 2006). Dalam menyelesaikan tugas tersebut, saat berinteraksi dengan orang lain maka akan meningkatkan keyakinan individu bahwa mereka dapat menguasai tugas-tugas dalam pengambilan keputusan karier.

\section{KESIMPULAN}

Berdasarkan hasil penelitian mengenai gambaran efikasi diri dalam membuat keputusan karier pada mahasiswa Unand, maka dapat disimpulkan bahwa :

1. Secara umum efikasi diri mahasiswa Unand dalam membuat keputusan karier berada pada taraf sedang. 
2. Secara keseluruhan, kelima aspek efikasi diri dalam membuat keputusan karier berada pada kategori sedang, yaitu aspek Self appraisal (penilaian diri) gathering occupational information (informasi pekerjaan), Goal selection (pemilihan tujuan), Planning (perencanaan), Problem solving (pemecahan masalah).

Beberapa saran yang dapat peneliti kemukakan :

1. Bagi Mahasiswa, hendaknya mulai mencari informasi karier sesuai dengan minat, potensi dan pilihan jurusan yang sedang ditekuni. Hal ini agar mereka dapat membuat perencanaan karier lebih jelas dengan langkah persiapan yang lebihmatang sehingga lebih mampu mengatasi persoalan yang muncul dikemudian hari.

2. Perlu peran orang tua dan upaya pihak universitas dalam mendampingi dan memberikan informasi yang dibutuhkan mahasiswa sehingga mereka lebih yakin dan siap menghadapi dunia kerja atau pendidikan setelah tamat nantinya. Selain itu juga perlu dirancangkan program pelatihan/penanganan yang mendukung dan memfasilitasi mahasiswa dalam mempersiapkan dan merencanakan karier dengan lebih maksimal. Hal ini agar mereka mendapatkan pengetahuan yang memadai sebelum memasuki dunia kerja. Selanjutnya orang tua dapat memberikan pendidikan agama, moral, sosial dan seksual untuk kesiapan secara psikologis mengahadapi dunia kerja (Ulwan, 2002).

3. Untuk peneliti selanjutnya dapat meneliti variabel efikasi diri dalam membuat keputusan karier dikaitkan dengan variabel lainnya baik yang terkait dengan faktor internal maupun eksternal. Penting bagi peneliti selanjutnya untuk mengontrol proses pengambilan data di lapangan sehingga data dari sampel penelitian dapat dikumpulkan sesuaidengan yang telah direncanakan.

\section{DAFTAR PUSTAKA}

Badan Pusat Statistik. (2015). Keadaan ketenagakerjaan Indonesia Februari 2015 (No. 47/05/Th. XVIII). Diakses dari http://bps.go.id

Badan Pusat Statistik Provinsi Sumatera Barat. (2015). Keadaan Ketenagakerjaan Sumatera Barat Februari 2015 (No. 31/5/13/Th XVIII). Diakses dari http://sumbar.bps.go.id

Bandura, A . 1997. Self efficacy in Changing Societes. New York: CambrigeUniversity Perss.

Betz, N. E., Hammond, M. S., \& Multon, K. D. (2005). Reliability and validity of five-level response continua for the Career Decision Self-Efficacy Scale. Journal of Career Assessment, 13(2), 131-149. doi: 10.1177/1069072704273123

Betz, N. E., Klein, K. L., \& Taylor, K. M. (1996). Evaluation of a Short Form of the Career Decision-Making Self-Efficacy Scale. Journal of Career Assessment, 4(1), 47-57. doi:10.1177/106907279600400103

Betz, N. E., \& Luzzo, D. A. (1996). Career Assessment and the Career Decision-Making SelfEfficacy Scale. Journal of Career Assessment, 4(4), 413428.doi:10.1177/106907279600400405 
Bozgeyikli, H., Bacanli, F. \& Dogan, H. (2009). Examination of 8th grade elementary school students' career decision making self-efficacy predictors. Selçuk ÜniversitesiSosyalBilimlerEnstitüsüDergisi, 21, 125-136.

Brown, D. (2002). Career choice and development $\left(4^{\text {th }} e d\right)$. Diakses dari http://www.borbelytiborbors.extra.hu/ZSKF/CareerDevelopment.pdf

Buyukgoze-Kavas, A. 2014. A Psychometric Evaluation of the Career Decision Self-Efficacy Scale-Short Form With Turkish University Students. Journal of Career Assessment, 22(2), 386-397. DOI: $10.1177 / 1069072713484561$

Chung, Y. B. (2002). Career decision making self efficacy and career commitment : gender and ethnic differences among college students. Journal of Career Development, 28(4), 277-284.

Creed, P.A., Patton, W., and Watson, M.B. (2003), Cross cultural equivalence of the CareerDecision-Making Self-EfficacyScale - Short Form: An Australian and South African comparison. Journal of Counseling and Development, Vol:74, p: 276-279.

Damayanti, D., \& Widyowati, A. (2018). Peningkatan career decison making self efficacy (CDMSE) melalui pelatihan perencanaan karier pada siswa SMK. Humanitas, 15(1), 35 45 .

Dybwad, T. E. (2009). Career maturity: A latent means and covariance structure analysis of Daidalos. Scandinavian Journal of Psychology, 50, 109-120. DOI: 10.1111/j.14679450.2008.00702.x.

Malik, R.L (2015). Kematangan Karier Mahasiswa Jurusan Tarbiyah Sekolah Tinggi Agama Islam Negeri (STAIN) Samarinda. Fenomena, 7(1), 109-128.

Papalia, D. E., Olds, S. W., \& Feldman, D. R. (2008). Human development: Perkembangan manusia: Buku 2 (10 thed).

Podiaro, F.T., Soetjiningasih, C.H., \& Prasetya, B.E.A. (2014). Hubungan Antara self efficacy pengambilan keputusan karier dnegan kematangan karier siswa SMK Sahid Surakarta. Fakultas Psikologi Universitas Kristen Satya Wacana.

Pratiwi, A. (2015). Gambaran kematangan karier mahasiswa Univeritas Andalas (Skripsi tidak dipublikasikan). Program Studi Psikologi Fakultas Kedokteran, Universitas Andalas, Padang.

Putri, I.D. (2017). Gambaran kesulitan pengambilan keputusan karier mahasiswa universitas andalas. Skripsi. Universitas Andalas : Program Studi Psikologi Fakultas Kedokteran.

Rachmawati, Y.E. (2012). Hubungan antara self efficacy dengan kematangan karier pada mahasiswa tingkat awal dan tingkat akhir di Universitas Surabaya. Jurnal Ilmiah Mahasiswa Universitas Surabaya, Vol.1. No. 1, 1-25

Reed, A.E., Mikels, J.A., \& Löckenhoff, C.E. (2012). Choosing with confi-dence : Self-efficacy and preferences for hoice. Judgment and Decision Making. 7(2), 173-180.

Santosa, E.I., \& Himam, F. 2014. Pengaruh berbagi pengetahuan perencanaan karier terhadap efikasi diri dalam membuat keputusan karier. Jurnal Intervensi Psikologi, 6 (1),1-24

Sawitri, D. R. (2008). Pengaruh status identitas dan efikasi diri keputusan Karier terhadap keraguan mengambil keputusan karier pada siswa SMA kelas 12. Tesis. (Tidak diterbitkan). Depok: Fakultas Psikologi Universitas Indonesia. 
Sawitri, D. R. (2009). Pengaruh status identitas dan efikasi diri keputusan karier terhadap keraguan mengambil keputusan karier pada mahasiswa tahun pertama di universitas diponegoro. Jurnal Psikologi Undip, 5(2). https://core.ac.uk/download/pdf/11708852.pdf

Seijts, G. H., Latham, G. P., Tasa, K., \& Latham, B.W. (2004). Goal Setting and Goal Orientation: An Integration of Two Different Yet Related Literatures. Academy of Management Journal, 47(2), 227-239. http://citeseerx.ist.psu.edu/viewdoc/download?doi=10.1.1.705.7789\&rep=rep1\&type=pdf

Stitt-Gohdes, W. L. (1997). Career development: Issues of gender, race, and class. Columbus, OH: Center on Education and Training for Employment, The Ohio State University. (ERIC Information Series No. 371)

Super, D. E., Thompson, A. S., Lindeman, R. H., Jordaan, J. P. \& Myers, R. A. (1981). Career Development Inventory volume $1:$ User's manual. http://www.vocopher.org/ncda2008/data/resources/CDIUserManual.pdf

Tabernero, C., \& Wood, R. E. (2009). Interaction between self-efficacy and initial performance in predicting the complexity of task chosen. Psychological Reports,105 (3), 11671180.doi:10.2466/pr0.105.f.1167-1180

Taylor, K. M., \& Betz, N. E. (1983). Applications of self-efficacy theory to the understanding and treatment of career indecision. Journal of Vocational Behavior, 22(1), 63-81. doi:10.1016/0001-8791(83)90006-4

Tomevi, Charlotte (2013) "Career-decision Self-efficacy Among College Students with Symptoms of Attention Deficit Disorder," McNair Scholars Research Journal, 9(1), Article 13. https://scholarworks.boisestate.edu/cgi/viewcontent.cgi?article=1130\&context=mcnair_jour nal

Ulwan, A.N. (2002). Tarbiyat al-Aulad fi al-islam. Terjemahan oleh Jamaluddin Miri. Jakarta: Pustaka Amani.

Umam, N.A.A. (2015). Hubungan antara self efficacy karier dengan kematangan karier siswa kelas XII SMA negeri 1 Karangananyar Kab. Demak. Skripsi. Jurusan Psikologi Fakultas Ilmu Pendidikan. Universitas Negeri Semarang

Vahedi, S., Farrokhi, F., Mahdavi, A., \& Moradi, S. (2012). Exploratory and confirmatory factor ananlysis of the Career Decision-Making Difficulties Questionaire. Iranian Journal Psychiatry, 7(2), 74-81.

Vertsberger, D., \& Gati, I. (2014). Career decision-making difficulties and help-seeking among Israeli young adults. Journal of Career Development, 43(2), 145-159.

Wang, N., Jome, L. M., Haase, R. F., \& Bruch M. A. (2006).The role of personality and career decision-making self-efficacy in the career choice commitment of college students. Journal Of Career Assessment, 14 (3), 312-332. doi: 10.1177/1069072706286474

Widyaningrum, D \& Hastjarjo, T. D. (2016). Pengaruh bimbingan karier terhadap efikasi diri dalam pengambilan keputusan karier pada siswa. Gadjah Mada Journal Of Psychology, 2(2), 86-100. 